\title{
FORMULASI DAN UJI STABILITAS FISIKA DAN KIMIA SEDIAAN SHAMPO ANTIKETOMBE EKSTRAK KULIT BUAH JERUK PURUT (Citrus hystrix Dc)
}

\author{
Formulation and Physical Stability Test for Anti-Dandruff Shampoo for Cortice Lime Extract Ethanol \\ Nielma Auliah, Muhammad Asri.SR, Sri Wahyuningsih \\ Universitas Megarezky \\ Email : nielmaauliah@gmail.com
}

\begin{abstract}
This study aims to formulate cortice lime extract ethanol (Citrus hystrix Dc.) into anti-dandruff shampoo with various concentrations of F1 without extract, F2 5\%, F3 10\% and F4 15\%. This type of research is in the form of laboratory trials with anti-dandruff shampoo testing including stability, organoleptic, $\mathrm{pH}$, viscosity and antifungal tests against Candida albicans fungi. The results showed that the anti-dandruff shampoo with a concentration of $5 \%$, $10 \%$, and $15 \%$ showed $\mathrm{pH}$ 5,2 - 6,8 which fulfilled the requirements for shampoo preparation, namely between 5.0-9.0. Organoleptically, the anti-dandruff shampoo preparation of cortice lime extract showed no change in odor, color and shape before and after accelerated storage, namely the shampoo preparation still has a distinctive odor, brown to dark brown in color and a slightly thick shape. The results of the antifungal activity study showed that the anti-dandruff shampoo formulation of cortice lime extract with a concentration of 5\%, 10\%, and $15 \%$ can inhibit the growth of Candida albicans fungi with an inhibitory zone response (strong-very strong). From the results of the research that has been done, it is known that the anti-dandruff shampoo for cortice lime extract is physically and chemically stable for organoleptic testing, pH, viscosity and effective as an anti-dandruff against the fungus Candida albicans
\end{abstract}

Keywords : Shampoo anti-dandruff, cortice lime extract ethanol

\section{ABSTRAK}

Penelitian ini bertujuan untuk memformulasikan ekstrak kulit buah jeruk purut (Citrus hystrix Dc.) menjadi sediaan Shampo Antiketombe dengan variasi konsentrasi F1 tanpa ekstrak, F2 5\%, F3 10\% dan F4 15\%. Jenis penelitian ini berupa eksperimen laboratorium dengan pengujian shampo antiketombe meliputi uji stabilitas, Organoleptik, Ph, Viskositas dan uji antijamur terhadap jamur Candida albicans. Hasil yang diperoleh yaitu shampo antiketombe dengan konsentrasi 5\%, 10\%, dan 15\% menunjukkan $\mathrm{Ph}$ 5,2 - 6,8 dimana memenuhi syarat sediaan shampo yaitu antara 5,09,0 . Secara organoleptis sediaan shampo antiketombe ekstrak kulit buah jeruk purut menunjukkan tidak ada perubahan bau, warna dan bentuk sebelum dan setelah penyimpanan dipercepat yakni sediaan shampo tetap memiliki bau yang khas, warna coklat hingga coklat tua dan bentuk yang agak kental. Hasil penelitian uji aktivitas antijamur menunjukkan Formulasi shampo antiketombe ekstrak kulit buah jeruk purut dengan konsentrasi $5 \%$, 10\%, dan $15 \%$ dapat menghambat pertumbuhan jamur Candida albicans dengan respon zona hambat (Kuat-sangat kuat). Dari hasil penelitian yang telah dilakukan, disimpulkan bahwa shampo antiketombe ekstrak kulit buah jeruk purut stabil secara fisika dan kimia untuk penujian organoleptis, $\mathrm{Ph}$, viskositas dan efektif sebagai antiketombe terhadap jamur Candida albicans.

Keywords : Shampo Antiketombe, Kulit Buah Jeruk Purut

\section{PENDAHULUAN}

Ketombe merupakan suatu keadaan anomali pada kulit kepala, yang dikarakterisasi dengan terjadinya pengelupasan lapisan tanduk secara berlebihan dari kulit kepala membentuk sisik-sisik yang halus. Penyebab ketombe dapat berupa sekresi kelenjar keringat yang berlebihan atau adanya peranan mikroorganisme di kulit kepala yang menghasilkan suatu metabolit yang dapat menginduksi terbentuknya ketombe di kulit kepala. Ketombe merupakan masalah yang sering dialami yang merupakan peranan dari mikroorganisme seperti jamur (Malonda et al, 2017). Penyakit yang ditimbulkan oleh jenis jamur adalah kandidiasis (kandidosis, moniliasis, thrush) adalah penyakit jamur akut atau subakut yang disebabkan oleh Candida, biasanya
Candida albicans). Hal tersebut tropis, bersuhu tinggi, dan memiliki kelembapan udara yang disebabkan karena jamur tersebut merupakan bagian dari mikroba flora normal yang beradaptasi dengan baik pada inang manusia, terutama saluran cerna, saluran urogenital, dan kulit (Bhaskara, 2012). Obat-obat tradisional telah banyak digunakan sebagai antiketombe. Salah satunya adalah Kulit jeruk purut. Salah satu tanaman herbal yang memiliki kandungan senyawa aktif yang diharapkan dapat dijadikan obat tradisional yaitu kulit jeruk purut (Khafidhoh et al, 2015). Kandungan utama kulit jeruk purut adalah pektin minyak atsiri. Kandungan pektin dalam kulit jeruk purut berkisar $15-25 \%$ dari berat kering.

Sedangkan kandungan minyak atsiri dalam kulit jeruk purut sekitar $70-92 \%$. 
Daun jeruk purut juga mengandung senyawa minyak atsiri, tetapi kadar minyak atsiri paling tinggi terdapat pada bagian kulit buah. Komponen utama dalam minyak atsiri kulit jeruk purut yang berfungsi sebagai antifungi adalah limorene $(29,2 \%)$ dan $\beta$-pinene $(30,6 \%)$.Selain minyak atsiri kulit jeruk purut juga mengandung senyawa saponin dan metabolit sekunder seperti flavonoid, kumarin, dan steroid tritreponoid. Saponin dan flavonoid merupakan golongan terbesar dari fenol. Menyatakan bahwa fenol dan persenyawaan dari fenolik merupakan unsur antifungi yang kuat ada konsentrasi yang biasa digunakan (larutan air 1-2\%). Fenol dan derivatnya dapat menimbulkan denaturasi protein, saponin diketahui memiliki sifat antimikroba sedangkan flavonoid mampu merusak membran mikroba (Iskandar, 2018). Senyawa kulit jeruk purut yang juga menunjukkan aktivitas antifungi yaitu saponin yang bereaksi dengan mengganggu membran sel fungi, salah satunya yaitu Candida albicans).

Selain itu kandungan senyawa antifungi lain seperti tanin, mempengaruhi perubahan permeabilitas membran sel yang dapat menyebabkan penurunan volume sel, sama halnya dengan saponin dan tanin, flavonoid juga dapat merusak membran sel sehingga terjadi perubahan permeabilitas sel, sedangkan kumarin merusak sel dengan membentuk pori-pori dinding sel sehingga menyebabkan kematian sel (Khafidhoh et al, 2015). Buah jeruk purut dilaporkan mampu menghambat pertumbuhan khamir penyebab ketombe Candida Albicans. Bagian kulit buah jeruk purut ternyata memiliki daya anti mikrob yang lebih kuat dibandingkan dengan buah jeruk purut (Zatalini, et al 2017). Pada penelitian sebelumnya belum ada penelitian tentang kulit buah jeruk purut (Citrus hystrix Dc.) sebagai anti ketombe, maka berdasarkan beberapa jurnal penelitian diatas peneliti tertarik untuk memformulasi sediaan shampo menggunakan limbah kulit buah jeruk purut (Citrus hystrix Dc) untuk dibuat sediaan farmasi dalam bentuk shampo antiketombe.

\section{METODE}

Jenis penelitian merupakan penelitian ekperimental laboratorium yaitu metode difusi agar dengan tehnik sumuran pada pengujian stabilitas fisika-kimia sediaan shampo antiketombe ekstrak etanol kulit buah jeruk purut (Citrus hystrix Dc) serta dilakukan penentuan konsentrasi hambat minimum (KHM).

\section{BAHAN}

Bahan yang digunakan yaitu Kulit buah jeruk purut (Citrus hystrx Dc), etanol $96 \%$, Air suling, Asam sitrat, HPMC, Natrium benzoat, Propilen glikol, dan Sodium lauril sulfat

\section{PROSEDUR KERJA :}

\section{A. Pengolahan sampel}

Sampel kulit jeruk purut (Citrus hystrix Dc), yang telah diambil akan dicuci bersih selanjutnya dilakukan perajangan dan bahan dipotong-potong kecil, kemudian dikeringkan dengan cara diangin-anginkan agar terlindung dari cahaya matahari langsung. Kulit buah jeruk purut (Citrus hystrix Dc.) ditimbang sebanyak $458 \mathrm{~g}$, dan ditambahkan etanol $96 \%$ Disimpan selama $3 \times 24$ jam pada suhu kamar dengan beberapa kali pengadukan. Kemudian dilakukan remaserasi hingga diperoleh ekstrak kental.

\section{B. Pembutan Shampo}

Shampo dibuat dengan cara mencampur ekstrak kulit jeruk purut (Citrus hystrix Dc.) dengan propilen glikol lalu dimasukkan asam sitrat dan natrium benzoat lalu geus hingga homogen, dimasukkan sedikit demi sedikit sodium lauryl sulfat dihomogenkan, dilarutkan hydroxyl propyl methyl cellulose (HPMC) menggunakan pelarut aquadest digerus hingga homogen, dimasukkan larutan hydroxyl propyl methyl cellulose (HPMC) kedalam lumpang yang berisi ekstrak kulit buah jeruk purut dan bahan tambahan lainnya. Digerus secara cepat hingga membentuk busa.

\section{Uji Stabilitas}

\section{Cycling Test}

Sediaan shampo disimpan pada suhu rendah selama 24 jam, lalu pindahkan ke suhu tinggi selama 24 jam (1 siklus). Lakukan sebanyak 6 siklus (12 hari)

\section{Uji Sifat Organoleptik}

Merupakan salah satu parameter fisik untuk mengetahui kestabilan dalam shampo. Uji penampilan fisik shampo antiketombe terdiri dari warna, bau, dan bentuk. Dengan 
cara mengamati warna yang nampak pada sediaan shampo antiketombe, dan mengidentifikasi bau dengan indera penciuman, serta melihat bentuk sediaan shampo.

3. $\mathrm{Ph}$

Pengukurn $\mathrm{Ph}$ shampo antiketombe dilakukan dengan cara, dikalibrasi alat $\mathrm{PH}$ meter menggunakan aquadest, setelah itu di ukur $\mathrm{PH}$ sediaan shampo antiketombe Konsentrasi $5 \%, 10 \%$ dan $15 \%$ dengan cara dicelupkan kedalam wadah gelas kimia yang telah berisi sediaan shampo antiketombe.

4. Viskositas Dan Sifat Alir

Viskositas dan sifat alir dilakukan menggunakan viskometer Brookfield Spindel 2 dengan 3 kecepatan yaitu 12 Rpm, 30 Rpm, 60 Rpm.

\section{Uji Akivitas Antijamur}

Pada pengujian ini dilakukan uji aktivitas sediaan shampo antiketombe ekstrak kulit buah jeruk purut (Citrus hystrix Dc.) sebagai antijamur terhadap Candida albicans dengan metode difusi agar menggunakan pencadang sebagai alat untuk membuat sumuran pada media agar yang telah diinokulasi dengan jamur Candida albicans. Pengujian metode difusi agar menggunakan sediaan shampo antiketombe ekstrak kulit buah jeruk purut (Citrus hystrix Dc.) dengan kadar konsentrasi $5 \%, 10 \%$, dan $15 \%$. Masing-masing dari setiap konsentrasi tersebut dilakukan replikasi pengujian sebanyak 3 kali. Dilakukan inkubasi pada suhu $37^{\circ} \mathrm{C}$, selanjutnya akan didapatkan diameter zona hambat di kategorikan menurut Davis dalam (Rahayu et al 2009), dan dilakukan penentuan konsentrasi hambat minimum (KHM).

\section{HASIL PENELITIAN}

Tabel 1.

Ekstraksi

\begin{tabular}{cccc}
\hline Jenis pelarut & $\begin{array}{c}\text { Berat sampel } \\
\text { kering }(\mathrm{g})\end{array}$ & $\begin{array}{c}\text { Berat } \\
\text { ekstrak }\end{array}$ & $\begin{array}{c}\text { Rendaman } \\
(100 \%)\end{array}$ \\
\hline Etanol 96\% & 458 & 40 & $10,075 \%$ \\
\hline
\end{tabular}

Tabel 2.

Uji Organoleptik

\begin{tabular}{|c|c|c|c|c|c|c|}
\hline \multirow{3}{*}{$\begin{array}{l}\text { Formula } \\
\text { Shampo }\end{array}$} & \multicolumn{6}{|c|}{ Pengamatan } \\
\hline & \multicolumn{3}{|c|}{ Sebelum Penyimpanan } & \multicolumn{3}{|c|}{ Setelah Penyimpanan } \\
\hline & Warna & Bau & Bentuk & Warna & Bau & Bentuk \\
\hline $\begin{array}{c}\mathrm{FI} \\
(\text { Tanpa ekstrak) }\end{array}$ & Bening basis & Khas & Agak Kental & Bening basis & Khas & Agak kental \\
\hline $\begin{array}{l}\text { FII } \\
(5 \%)\end{array}$ & Coklat & Khas & Agak Kental & Coklat & Khas & Agak Kental \\
\hline $\begin{array}{c}\text { FIII } \\
(10 \%)\end{array}$ & coklat & Khas & Agak Kental & Coklat & Khas & Agak kental \\
\hline $\begin{array}{c}\text { FIV } \\
(15 \%)\end{array}$ & Coklat tua & Khas & Kental & Coklat tua & Khas & Kental \\
\hline
\end{tabular}


Tabel 3.

Pengukuran pH

\begin{tabular}{ccc}
\hline $\begin{array}{c}\text { Konsentrasi } \\
(\%)\end{array}$ & $\begin{array}{c}\text { Sebelum } \\
\text { penyimpanan }\end{array}$ & $\begin{array}{c}\text { Sesudah } \\
\text { penyimpanan }\end{array}$ \\
\hline FI & 7,3 & 7,3 \\
FII (5\%) & 5,2 & 5,3 \\
FIII (10\%) & 6,6 & 5,8 \\
FIV (15\%) & 6,8 & 6,2 \\
\hline
\end{tabular}

Tabel 4.

Uji Viskositas

\begin{tabular}{ccc}
\hline Formula & \multicolumn{2}{c}{ Pengamatan } \\
\cline { 2 - 3 } Shampo & $\begin{array}{c}\text { Sebelum } \\
\text { Penyimpanan }\end{array}$ & $\begin{array}{c}\text { Setelah } \\
\text { Penyimpanan }\end{array}$ \\
\hline FI & $2,50 \mathrm{mPas}$ & $47,50 \mathrm{mPas}$ \\
$\mathrm{FII}(5 \%)$ & $37,50 \mathrm{mPas}$ & $40,00 \mathrm{mPas}$ \\
FIII $(10 \%)$ & $75,0 \mathrm{mPas}$ & $77,5 \mathrm{mPas}$ \\
FIV $(15 \%)$ & $327,5 \mathrm{mPas}$ & $552 \mathrm{mPas}$ \\
\hline
\end{tabular}

Tabel 5.

Cycling Test

\begin{tabular}{|c|c|c|c|c|c|c|}
\hline \multirow{2}{*}{$\begin{array}{l}\text { Formula } \\
\text { Shampo }\end{array}$} & \multirow{2}{*}{ Pengamatan } & \multicolumn{2}{|c|}{ Suhu $4^{\circ} \mathrm{C}$} & \multicolumn{2}{|c|}{ Suhu $40^{\circ} \mathrm{C}$} & \multirow[t]{2}{*}{ Kristalisasi } \\
\hline & & Awal siklus & Akhir siklus & Awal siklus & Akhir siklus & \\
\hline $\begin{array}{c}\text { F1 } \\
\text { (Tanpa ekstrak) }\end{array}$ & $\begin{array}{c}\text { Warna } \\
\text { Bau } \\
\text { Bentuk }\end{array}$ & $\begin{array}{c}\text { Bening } \\
\text { Khas } \\
\text { Agak Kental }\end{array}$ & $\begin{array}{c}\text { Bening } \\
\text { Khas } \\
\text { Agak kental }\end{array}$ & $\begin{array}{c}\text { Bening } \\
\text { Khas } \\
\text { Agak kental }\end{array}$ & $\begin{array}{c}\text { Bening } \\
\text { Khas } \\
\text { Agak kental }\end{array}$ & Tidak \\
\hline $\begin{array}{l}\mathrm{F} 2 \\
(5 \%)\end{array}$ & $\begin{array}{c}\text { Warna } \\
\text { Bau } \\
\text { Bentuk }\end{array}$ & $\begin{array}{c}\text { Coklat } \\
\text { Khas } \\
\text { Agak Kental }\end{array}$ & $\begin{array}{c}\text { Coklat } \\
\text { Khas } \\
\text { Agak kental }\end{array}$ & $\begin{array}{c}\text { Coklat } \\
\text { Khas } \\
\text { Agak kental }\end{array}$ & $\begin{array}{c}\text { Coklat } \\
\text { Khas } \\
\text { Agak kental }\end{array}$ & Tidak \\
\hline $\begin{array}{c}\text { F3 } \\
(10 \%)\end{array}$ & $\begin{array}{l}\text { Warna } \\
\text { Bau } \\
\text { Bentuk }\end{array}$ & $\begin{array}{l}\text { Coklat } \\
\text { Khas } \\
\text { Kental }\end{array}$ & $\begin{array}{l}\text { Coklat } \\
\text { Khas } \\
\text { Kental }\end{array}$ & $\begin{array}{l}\text { Coklat } \\
\text { Khas } \\
\text { Kental }\end{array}$ & $\begin{array}{l}\text { Coklat } \\
\text { Khas } \\
\text { Kental }\end{array}$ & Tidak \\
\hline $\begin{array}{c}\mathrm{F} 4 \\
(15 \%)\end{array}$ & $\begin{array}{l}\text { Warna } \\
\text { Bau } \\
\text { Bentuk }\end{array}$ & $\begin{array}{c}\text { Coklat tua } \\
\text { Khas } \\
\text { kental }\end{array}$ & $\begin{array}{c}\text { Coklat tua } \\
\text { Khas } \\
\text { Kental }\end{array}$ & $\begin{array}{c}\text { Coklat tua } \\
\text { Khas } \\
\text { Kental }\end{array}$ & $\begin{array}{c}\text { Coklat tua } \\
\text { Khas } \\
\text { Kental }\end{array}$ & Tidak \\
\hline
\end{tabular}

Tabel 6.

Diameter Zona hambat

\begin{tabular}{|c|c|c|c|c|c|c|c|}
\hline \multirow{2}{*}{ Sampel } & \multirow{2}{*}{ Konsentasi } & \multicolumn{3}{|c|}{ Diameter zona hambat (mm) } & \multirow{2}{*}{$\begin{array}{l}\text { Rata-rata } \\
\quad(\mathrm{mm})\end{array}$} & \multirow{2}{*}{$\begin{array}{l}\text { Hasil } \\
(\mathrm{mm})\end{array}$} & \multirow{2}{*}{$\begin{array}{c}\text { Zona } \\
\text { hambat }\end{array}$} \\
\hline & & I & II & III & & & \\
\hline \multirow{3}{*}{$\begin{array}{l}\text { Shampo Ekstrak Kulit } \\
\text { Buah Jeruk Purut }\end{array}$} & FII (5\%) & 19,3 & 20,3 & 20 & 19,8 & 14,8 & Kuat \\
\hline & FIII(10\%) & 23,6 & 22,6 & 21,6 & 22,6 & 17,6 & Kuat \\
\hline & FIV(15\%) & 35,6 & 35,3 & 33 & 34,6 & 29,6 & Sangat kuat \\
\hline
\end{tabular}


ISSN : 2549-0567 (Online) 


\section{PEMBAHASAN}

Pada pemeriksaan organoleptis sediaan, didapatkan sediaan formula tanpa ekstrak yang bening, bau khas, bentuk kental. Pada formula konsentrasi 5\% didapat sediaan berwarna coklat muda, bau khas, bentuk agak kental. Pada konsentrasi $10 \%$ berwarna coklat, bau khas, bentuk agak kental dan Konsentrasi $15 \%$ berwarna coklat, bau khas, bentuk agak kental. Perbedaan warna pada formula konsentrasi $5 \%, \quad 10 \%, \quad 15 \%$ disebabkan karena penambahan ekstrak kulit buah jeruk purut. Pada konsentrasi 5\% berwarna coklat muda karena penambhan ekstrak kulit buah jeruk purut dalam jumlah sedikit 5 gram sedangkan pada konsentrasi $10 \%$ berwarna coklat sama halnya dengan konsentrasi $15 \%$ berwarna coklat dan tercium aroma yang khas kulit jeruk purut hal ini disebabkan karena penambahan ekstrak kulit buah jeruk purut dalam jumlah yang lebih banyak. Hasil ini menunjukkan bahwa keempat formula memenuhi persyaratan. Pemeriksaan $\mathrm{pH}$ untuk siklus awal $4^{\circ} \mathrm{C}$ hingga akhir pada suhu $4^{\circ} \mathrm{C}$ untuk konsentrasi $5 \%, 10 \%, 15 \%$ menunjukkan nilai 5.2, 6.6, 6.8. Dan hasil untuk suhu $40^{\circ} \mathrm{C}$ hasil yang diperoleh dari siklus awal dan akhir untuk konsentrasi 5\%, 10\% 15\% menunjukkan nilai $5.3,5.6,6.2$. Terjadi perubahan $\mathrm{pH}$ yang tidak begitu signifikan hal ini disebabkan karena kondisi suhu, adanya perubahan suhu yang drastis dari $4^{\circ} \mathrm{C}$ ke $40^{\circ} \mathrm{C}$. Nilai ini berada rentang syarat $\mathrm{pH}$ shampo yaitu 5-9 dan menunjukkan bahwa tidak ada perbedaan berarti, sehingga dapat dinyatakan $\mathrm{pH}$ sediaan stabil (Jessie et al 2014). Uji viskositas dilakukan untuk mengetahui besarnya suatu viskositas dari sediaan, dimana nilai viskositas tersebut menyatakan besarnya tahanan suatu cairan untuk mengalir. Makin tinggi nilai Viskositas maka makin besar daya tahan untuk mengalir, diutarakan oleh (R.Voight,1994). Hasil Pengukuran viskositas Shampo menggunakan Viscometer Brokfield (DV-E Viscometer) dengan menggunakan spindle no 2 dengan kecepatan $12 \mathrm{Rpm}$, sebelum dan sesudah kondisi penyimpanan dipercepat, menunjukkan adanya perubahan. Viskositas sediaan shampo pada F1 konsentrasi tanpa ekstrak kulit buah jeruk purut (Citrus hystrix Dc.) kenaikan dari 2,50 mPas menjadi 47,50 $\mathrm{mPas}$ setelah penyimpanan, untuk $\mathrm{F} 2$ konsentrasi $5 \%$ mengalami kenaikan dari
37,50 mPas menjadi 40,00 mPas, untuk konsentrasi $10 \%$ mengalami kenaikan dari $75,0 \mathrm{mPas}$ menjadi $77,5 \mathrm{mPas}$, dan untuk konsentrasi $15 \%$ mengalami kenaikan dari 327,5 menjadi 552 mPas. Terjadi perubahan Kenaikan viskositas disebabkan karena pada penyimpanan terakhir pada akhir uji cycling tes yaitu pada suhu rendah $4^{\circ} \mathrm{C}$. Hal ini dikarenakan pada suhu rendah partikel dalam sediaan shampo akan cenderung bergabung atau saling berdekatan membentuk struktur ikatan yang lebih rapat, sehingga kekentalan shampo ekstrak jeruk purut akan lebih meningkat (Jusnita, et al 2017). Pengujian Cycling Test dilakukan untuk menguji kemungkinan sediaan mengalami kristalisasi atau berawan (Nurdin,2015). Uji ini dilakukan dengan menyimpan masingmasing sediaan pada suhu $4^{\circ} \mathrm{C}$ selama 24 jam didalam kulkas, lalu dikeluarkan dan ditempatkan pada suhu $40^{\circ} \mathrm{C}$ selama 24 jam dioven. Perlakuan ini adalah satu siklus. Percobaan diulang sebanyak 6 siklus untuk memperjelas perubahan yang terjadi (Rachman,2010). Berdasarkan pengamatan organoleptis keempat formula sediaan Shampo antiketombe tetap stabil dengan tidak ditemukan adanya kristalisasi dan sediaan tetap jernih. Hal ini menunjukkan kecocokan bahan aktif dan bahan tambahannya (Voight, 1995). Pengujian aktivitas sediaan shampo antiketombe ekstrak kulit buah jeruk purut (Citrus hystrix Dc.) sebagai antijamur terhadap Candida albicans menunjukkan bahwa memiliki aktivitas antijamur. Hal ini ditandai dengan terbentuknya zona hambat bening disekitar sumuran yang telah diberi sediaan shampo ekstrak kulit buah jeruk purut (Citrus hytrix Dc.) setelah diinkubasi selama $2 \times 24$ jam. Pada konsentrasi 5\% memiliki diameter zona hambat sebesar 14 , $8 \mathrm{~mm}$, konsentrasi $10 \%$ diameter zona hambat sebesar $17,6 \mathrm{~mm}$, dan konsentrasi $15 \%$ diameter zona hambat 29,6 mm, sedangkan pada kontrol negatif tidak ada diameter hambat dikarenakan tidak memiliki aktivitas antijamur. Sesuai dengan kategori zona hambat maka hasil pengujian aktivitas sediaan shampo antiketombe ekstrak kulit buah jeruk purut (Citrus hystrix Dc.) sebagai antijamur terhadap Candida albicans menunjukkan daya antijamur yang sangat kuat pada variasi konsentrasi sediaan shampo ekstrak kulit buah jeruk purut (Citrus hystrix Dc.) pada konsentrasi $15 \%(29,6 \mathrm{~mm})$ dan kuat pada konsentrasi 
10\% $(17,6 \mathrm{~mm})$ dan $5 \%(14,8 \mathrm{~mm})$. Hasil pengujian yang telah dilakukan menunjukkan bahwa Konsentrasi Hambat Minimum (KHM) dari sedian shampo antiketombe esktrak kulit buah jeruk purut (Citrus hystrix Dc.) terhadap Candida albicans dengan konsentrasi $15 \%$ tersebut sudah efektif dalam menghambat pertumbuhan jamur uji. Besar kecilnya daya hambat yang terbentuk dikarenakan adanya perbedaan konsentrasi pada sediaan, dimana semakin besar konsentrasi semakin banyak pula komponen zat aktif yang terdapat didalamnya sehingga daya hambatan yang terbentuk juga berbeda dan menjadi parameter keefektifan dari sampel uji dalam menghambat atau membunuh jamur uji.

\section{KESIMPULAN}

1. Formulasi sediaan shampo antiketombe ekstrak kulit buah jeruk purut (Citrus hystrisx Dc.) stabil secara fisika, berdasarkan dari hasil pengamatan yang dilakukan menunjukkan bahwa Organoleptik memiliki bau khas, bentuk agak kental dan berwarna coklat. $\mathrm{Ph}$ shampo memenuhi syarat 5-6, untuk viskositas konsentrasi $5 \%$ dan $10 \%$ memenuhi syarat .

2. Formulasi sediaan shampo antiketombe ekstrak kulit buah jeruk purut (Citrus hystrisx Dc.) efektif sebagai anti ketombe. Hal ini menunjukkan bahwa respon zona hambat terhadap jamur Candida albicans (kuat hingga sangat kuat).

\section{DAFTAR PUSTAKA}

Ambarwati, et al., 2017 Kombinasi Ekstrak Daun Pandan Wangi (Pandanus amaryllifolius Roxb.) Dan Buah Mengkudu (Morinda citrifolia) Sebagai Antifungi Terhadap Jamur Penyebab Ketombe. Universitas muhammadiyah. Surakarta

Bhaskara G.Y., 2012. Uji Daya Antifungi Ekstrak Etanol Daun Salam (Syzygium polianthum [Wight] Walp.) Terhadap Candida Albicans Atcc
10231 Secara In Vitro. Universitas Muhammadiyah. Surakarta

Iskandar Dhoni., 2018, Uji Efektivitas Kulit Jeruk Purut (Citrus hystrix Dc.) Terhadap Pertumbuhan Jamur Candida Albicans Dengan Mtode Difusi. Sekolah tinggi ilmu kesehatan insan cendekia medika. Jombang

Khofidhoh Zakiyatul.,et al., 2015. Efektivitas Infusa Kuit Jeruk Purut (Citrus hystrix Dc.) Terhadap Pertumbuhan Candida albicans Penyebab Sariawan Secara in vitro. Universits Muhammadiyah. Semarang

Kusumadewi., 2003, Rambut Anda, Masalah, Perawatan, Dan Penataannya. PT. Gramedia Pustaka Pratama. Jakarta

Malonda, T.C., et al, 2017.Formulasi Sediaan Sampo Antiketombe Ekstrak Daun Pacar Air (Impatiens balsamina L.) Dan Uji Aktivitasnya Terhadap Jamur Candida Albicans Atcc 10231 Secara In Vitro. Universitas sam ratulangi. Manado

Ma'rufah Rodiah., 2017. Formulasi Gel Sampo Antiketombe Dari Minyak Atsiri Sereh Dapur (Cymbopogon citratus) Dan Aktivitasnya Terhadap Jamur Penyebab Ketombe (Pityrosporum ovale). Universitas Sumatera Utara. Medan

Saraswati R.A,.et al,. 2015,.Formulasi shampoo anti ketombe dan Anti Kutu Rambut Dari Berbagai Macam Tanaman Herbal,. Fakultas Farmasi Universitas Padjajaran,. Bandung

SagrimM. E.A.U., et al 2015, Perawatan Intensif Serum Rambut Dari Ekstrak Kemangi (Ocimum basilicum) Untuk Rambut Sehat Alami. Universitas Sebelas Maret. Surakarta.

Warsito., 2018. Derivatisasi Sitronelal. UB Press. Malang

Zatalini D.F., 2017, Formulasi dan uji aktivitas Gel HPMC-Kitosan Terhadap Proses Penyembuhan Luka Bakar Derajat IIA Pada Tikus Putih (Rattus norvegicus) Galur Wistar. Universitas Islam Negeri Maulana Malik. 